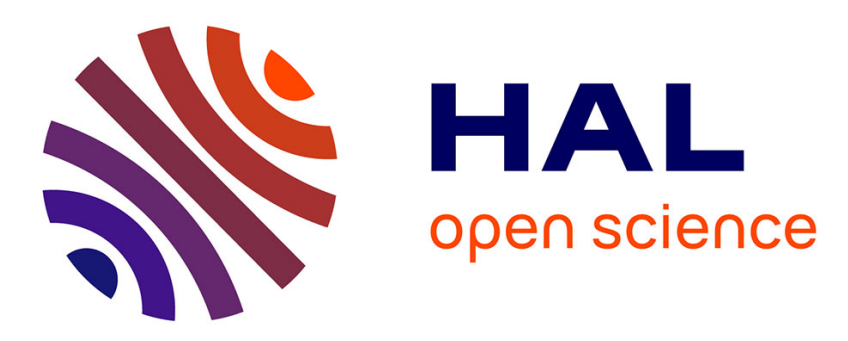

\title{
Design of equipment for agroecology: Coupled innovation processes led by farmer-designers
}

Chloé Salembier, Blanche Segrestin, Nicolas Sinoir, Joseph Templier, Benoit

Weil, Jean-Marc Meynard

\section{- To cite this version:}

Chloé Salembier, Blanche Segrestin, Nicolas Sinoir, Joseph Templier, Benoit Weil, et al.. Design of equipment for agroecology: Coupled innovation processes led by farmer-designers. Agricultural Systems, 2020, 183, pp.102856. 10.1016/j.agsy.2020.102856 . hal-03108292

\section{HAL Id: hal-03108292 \\ https:/ /hal-mines-paristech.archives-ouvertes.fr/hal-03108292}

Submitted on 25 Jan 2021

HAL is a multi-disciplinary open access archive for the deposit and dissemination of scientific research documents, whether they are published or not. The documents may come from teaching and research institutions in France or abroad, or from public or private research centers.
L'archive ouverte pluridisciplinaire HAL, est destinée au dépôt et à la diffusion de documents scientifiques de niveau recherche, publiés ou non, émanant des établissements d'enseignement et de recherche français ou étrangers, des laboratoires publics ou privés. 
1 Design of equipment for agroecology: coupled innovation processes led by

\section{2 farmer-designers}

3 Chloé Salembier ${ }^{1}$, Blanche Segrestin², Nicolas Sinoir ${ }^{3}$, Joseph Templier ${ }^{3}$, Benoît Weil ${ }^{2}$, Jean-Marc

4 Meynard 1

${ }^{1}$ UMR Sad-Apt, INRAE, AgroParisTech, Université Paris-Saclay, 75005, Paris, France

2MinesParisTech, PSL Research University, Centre de Gestion Scientifique, UMR 9217 (I3), 75006 , Paris, France

3L'Atelier Paysan, ZA des papeteries, 38140 Renage, France

Corresponding author: Chloé Salembier, chloe.salembier@inrae.fr, UMR Sad-Apt, INRAE, AgroParisTech, Université Paris-Saclay, 75005, Paris, France

\section{Abstract}

More and more questions are currently being raised as to what the farm equipment of the future ought to be and how it should be designed to best meet contemporary challenges in farming. In Western countries, innovation in agricultural equipment is focused on a dominant model in which the agroindustry designs and patents standardised equipment for farmers. However, today's ambitions for agriculture, with agroecology in the lead, require us to devise farming systems that are adaptable to social and ecological uncertainties, and to recognise and embrace the diversity of situations in which farming is practiced. There has until now been little research on equipment design processes consistent with these principles, and this research helps to fill this gap. To address this issue, we studied the French "Atelier Paysan" R\&D organisation, created to support on-farm design of suitable equipment for agroecology. Based on design theories, we analysed three aspects of Atelier Paysan's design activities: specific properties of the equipment designed under its aegis; specific features of the design processes; and roles that Atelier Paysan takes on to enable the design of this equipment. Our results show that all the equipment designed was appropriate for the designers' situations and requirements, and adaptable to other situations. It emerged from design processes in which the farmers had the support of $R \& D$ to design both their own equipment and the cropping systems for which it would be used. We call this the design of coupled innovations, and show that farm equipment 
and cropping systems are designed together during experimental trials. Lastly, we show that the

Atelier Paysan R\&D organisation supports these design processes in three ways: it enables farmers to share their experiences of on-farm design; it makes available a set of resources to stimulate farmerdriven design of new equipment; and it brings together designers scattered all over France around a shared ambition for agriculture. This work opens up avenues for research: (i) to explore an alternative to the dominant design, which would rely on coupled innovation design processes and allow for the emergence of appropriate and adaptable equipment that complies with agroecological principles; and (ii) to explore ways of organising open-innovation processes for agroecology, by supporting farmerdesigners, and thus rethinking the roles of 'users' in these processes.

Key words: adaptability, agricultural machinery, Atelier Paysan, implement, open-innovation, tracking innovations

\section{Introduction}

Advances in agricultural equipment have always played a major role in the evolution of agriculture

(e.g. Sigaut, 1989). Questions are increasingly being raised today as to what the farm equipment of the future ought to be, and how it should be designed to best meet contemporary challenges in agriculture (Pisante et al., 2012; Sims and Kienzel, 2015; Bellon and Huyghe, 2017; Kirui and Braun, 2018). In Western countries, innovation in agricultural equipment currently focuses on a dominant design (e.g. FAO, 2013; Guillou et al., 2013; Bournigal, 2014), which very largely fits what Mazoyer and Roudard (2006) call the "motorised mechanisation" of agriculture that emerged in the mid-20th century. This has evolved into equipment incorporating digital technology, as attested by the frequent references in the literature to such concepts as "smart farming" (e.g. Wolfert et al., 2017; RelfEckstein et al., 2019), "agriculture 4.0" (e.g. Huh and Kim, 2018), "digital agriculture" or "agricultural robotics" (e.g. Ramin Shamshiri et al., 2018), and stated priorities in government support for agricultural innovation (e.g. the Agriculture-Innovation 2025 en France report includes "digital agriculture" and "robotic agriculture" as priorities). The challenges for designers of this equipment are to increase "reliability, efficiency and precision" (Bournigal, 2014) and to optimise farmers' actions by cutting input wastage, reducing occupational hazards and making equipment more ergonomic. 
Some authors write about equipment that fosters farmers' "autonomy", by which they mean cutting working hours or reconfiguring crop management tasks, which are partly taken over by computerised systems. One emblematic example is precision farming, in which fertiliser or pesticide applications are optimally managed in the field with the aid of spatialised data provided by onboard sensors on the equipment (Lindblom et al., 2016).

60 Today, most farm equipment is designed by manufacturers that market patented equipment (FouratiJamoussi, 2018) built from new materials and intended for large-scale, often international markets. The equipment designed is standardised (Piovan, 2018) for use in the most typical farming systems of the market: farms using chemical inputs on large fields (Onwude et al., 2016). For these firms, the main drivers of innovation are "customer demand and differentiation from competitors, (...) cutting production costs and complying with environmental standards and regulations" (Bournigal, 2014). From this standpoint, "innovative" is defined by the agro-industry and helps to rejuvenate the market offering.

In most European countries, this entrepreneurial drive in the private sector is accompanied by public sector withdrawal from research (Guillou et al., 2013), and the few scientific studies on the subject mainly concern improving sensors and onboard digital tools for precision agriculture (Bournigal, 2014). Meanwhile in the agronomy literature, articles on support for the design of agricultural systems (e.g. Rapidel et al., 2009; Ronner et al., 2019) regard equipment as a contingent variable and not as objects to be designed - that is, if they mention it at all. This situation reflects the compartmentalisation of research described by Piovan (2018), with research on farm equipment separate from agronomy research.

By contrast, today's ambitions for agriculture, with agroecology in the lead, introduce new challenges such as: recognising the diversity of farmer's situations and expectations (Altieri, 2002); considering uncertainty associated with poorly known agroecological systems (Brugnach et al., 2008); or also developing system approaches and fostering the open-sharing of knowledge, ideas and know-how while re-designing farming systems (Meynard et al., 2012). These issues highlight the limitations of the dominant design: how can standardised farm equipment meet the needs and expectations of 
farmers working in diverse agricultural situations (Nicholls and Altieri, 2018)? How can equipment

83 designed off-farm be made to fit technical systems designed in situ, and cope with the social,

84 ecological or economic uncertainties inherent to eco-friendly systems (Brugnach et al., 2008)? Do patents and digital tools not obstruct the ability of farmers to repair and transform their equipment (Ploeg, 2008; Coolsaet, 2016)?

Several studies have highlighted alternative processes for farm equipment design. The processes described are always more open, and suggest the need to review the roles of the parties involved. Bellon and Huyghe (2017), for example, stress the importance of involving the farmer-users at the start of the design process, to enable them to express their needs, and to make it more likely that the design will find a use. Lucas and Gasselin (2016) show that, in the networks of farmers linked to cooperatives for the use of agricultural equipment (CUMA, in France), the sharing of equipment increases the ability to adapt practices in an uncertain environment, and to engage in new and/or diverse practices on a farm by reducing individual investment costs and risks (Lucas et al., 2018). In these situations, the equipment already exists and farmers share its use.

Some articles mention other challenges: "How can farm equipment that does not yet exist be designed for agricultural systems that do not yet exist either?" (Bournigal, 2014), or "Another major obstacle is to be found in the lack of interaction between farm machinery designers, on the one hand, and designers of new cultivation and breeding systems, on the other: a joint working between them is urgently needed." (Bellon and Huyghe, 2017), or yet "farm equipment can be thought of as resources that do more than just respond to demand, because they foster the establishment of agroecology" (Piovan, 2018).

103 Our study is in line with this research trend and aims to contribute to a theorisation of the processes of

104 designing equipment for agroecology. More precisely, the intention is to shed light on features of 105 equipment design processes that are consistent with agroecological principles. With this aim, we use a 106 case study approach in this research, and in so doing we harness theoretical inputs from design 107 sciences and agronomy. 
108 We first present the conceptual framework we have adopted (2), then detail the research method we

109 used (3), present our findings (4), and close with a discussion of the main results (5).

\section{2. Conceptual framework}

111 What is a 'design process'? Various theories of design activities have been proposed in the literature.

112 Many of these are rooted in the proposals of Simon, who in the 1960s introduced what he called a

113 'science of the artificial' (Simon, 1969). Subsequent work has enriched, discussed and even challenged

114 some of his proposals, notably by introducing new notions and new modelling (e.g. Yoshikawa, 1981;

115 Gero and Kannengiesser, 2008). In this article, we draw on notions and concepts associated with the

116 Concept-Knowledge (CK) theory (Hatchuel and Weil, 2002, 2003, 2009) and the work of Schön

117 (1983). We consider "design" as a process driven by a desire to generate something that does not yet

118 exist. This process is manifest in the actions of one or more designers, in the gradual emergence of a

119 new object, either material or immaterial, and in its integration into physical, social, economic and

120 virtual environments (Papalambros, 2015; Wynn and Clarkson, 2018; Hatchuel et al., 2017).

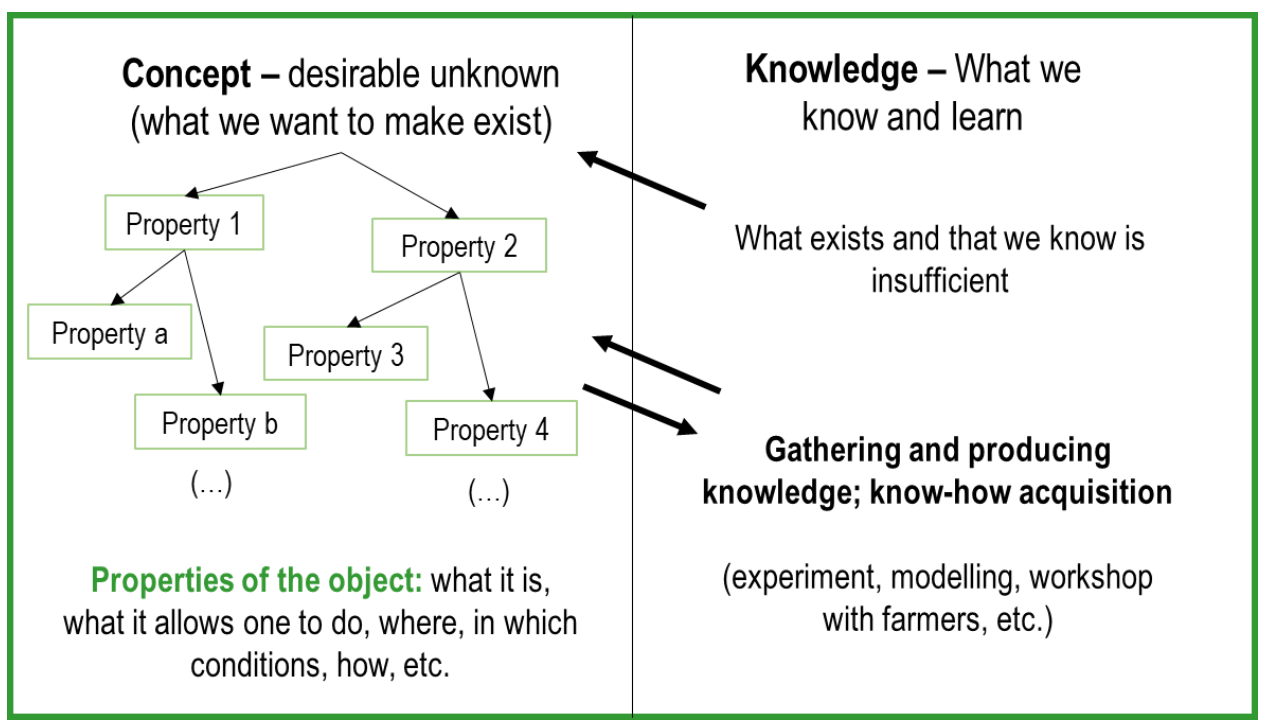

122 Figure 1. Modelling of a design process related to the CK theory (adapted from Hatchuel and Weil,

123 2003). On the left is the space of 'concepts', i.e. a space of the desirable unknown; where the logical

124 status of a design proposal is neither true or false. On the right is the space of 'knowledge', i.e. what

125 we know and what we learn; and where the logical status of a design proposal can be true or false. In

126 the concept space, new designed objects that do not yet exist emerge, by the progressive definition of 
127 their properties (which progressively gain a logical status in the knowledge space). The temporality of

128 the design process on the figure is represented from top to bottom. The arrows in the centre illustrate

129 the dialogue that takes place during design between the production of knowledge and the progressive

130 definition of a new object.

131 As mentioned by Hatchuel and Weil (2009), in the course of this process, the identity of a new object

132 desired by a designer is defined (Figure 1), so that its properties progressively emerge: its 133 composition, the use that can be made of it, by whom, when, in what conditions, etc. To start a design 134 process, one must formulate a desirable unknown (Le Masson et al., 2017). In other words, for the 135 designer, what exists is insufficient and he/she wants something new to emerge (which is desirable), 136 but he/she does not yet know what (it is unknown). The design process is a highly dynamic and 137 collective one (see Figure 1, Hatchuel and Weil, 2009): a new object is defined over time, through 138 iterations between specifying its properties, acquiring knowledge and negotiating between designers 139 and with other actors. In addition, by introducing the seeing-moving-seeing mechanism, Schön (1983) 140 places the situation of action and its materiality at the heart of the design process, and insists on the 141 fact that it is in and through action that a new object emerges. This proposition is based on the 142 observation that one cannot imagine all the dimensions of an object before having acted: only action 143 makes it possible to discover certain dimensions and thus to manage the complexity of the object 144 during its emergence.

145 Agroecology calls for the redesign of agricultural systems (Meynard et al., 2012), which R\&D actors 146 can support, for instance, by generating resources to support change, such as decision support 147 systems, trainings, design support tools (Salembier et al., 2018). However, several authors mention 148 that this project demands an in-depth reconsideration of the design processes. For instance, they raise 149 the following questions: how can systemic interactions and uncertainties in local agro-ecosystems be 150 taken into account during design (Prost et al., 2016; Darnhofer et al., 2010)? How can the ecological 151 and social particularities of each farm be taken into account during these processes? Or even, what 152 roles should the parties involved take on in order to move towards 'open innovation' organisations 153 (Chesbrough et al., 2014; Berthet et al., 2018; Kilelu et al., 2013; Joly, 2017), which seem conducive 
154 to agroecology? Our work has explored the features of equipment design processes for agroecology in

155 relation to these questions.

\section{3. Case description and research method}

157 This exploratory study is based on a single case (Yin, 2003; Siggelkow, 2007). By choosing this method and adopting an inductive research strategy, our aim was to contribute to a theory on the processes of designing equipment for agroecology. Our investigation focuses on a French

160 organisation called Atelier Paysan.

\subsection{The case study: Atelier Paysan}

Atelier Paysan defines itself as "a collective of small farmers, employees and agricultural extension structures" gathered around the shared objective of "increasing farmers' autonomy in developing suitable farm equipment for agroecology" (Atelier Paysan website - https://www.latelierpaysan.org/).

165 The idea of creating Atelier Paysan emerged in 2009 from several observations: (i) the agricultural 166 equipment currently on the market is ill-suited to the particularities of organic farming and is costly, 167 opaque ("black box" systems) and requires expert intervention for repairs; (ii) on farms dotted around

168 France, there exist a number of implements invented and built by farmers themselves to suit their particular organic farming practices, and which are easy to repair, to modify; (iii) this equipment, used only on the farms where it is made, remains invisible to the farming world at large; and (iv) most farmers lack the skills to invent and build equipment that fits their situations.

Atelier Paysan was incorporated as a cooperative (Société Coopérative d'Intérêt Collectif-SCIC) in 2014. This status means that users, employees and partners can work together within one company. It allows them to formalise the shared values of their collective ambition for agriculture, such as farmerdriven design, pesticide-free agriculture or agroecological practices. Atelier Paysan is $70 \%$ self-

176 financed (from training, margin on equipment sales, private funding, etc.) and $30 \%$ funded by 177 government subsidy. In 2020, the Atelier Paysan counts 22 permanent workers and involves occasional volunteers and trainees. 
Tracking farmers' innovations
Supporting groups designing appropriate equipment

Drawing up specifications for farm equipment

Modelling, producing 3D technical drawings

Prototyping equipment

Running experiments

Publishing open-source equipment building tutorials

Running a network of DIY farm equipment builders
Organising hands-on training for building DIY farm equipment

Bulk ordering of materials and accessories

Disseminating manuals for DIY farm equipment building

Running a website and Internet forum

179 Table 1. The two overarching activities described on the Atelier Paysan website and their associated

180 sub-activities (table drawn up from Atelier Paysan website on 12/01/2019)

181 Atelier Paysan organises its work around two overarching themes (Table 1): (i) participative R\&D, 182 which includes activities such as innovation tracking, producing 3D technical drawings of equipment 183 and providing support for groups designing their own equipment, and (ii) disseminating farmers' 184 skills and knowledge, which includes organising hands-on training in Do It Yourself (DIY) farm 185 equipment building or running an Internet forum.

186 Since its creation, the cooperative has increased its audience. Today, more than 1000 implements 187 designed by farmers across France have been recorded, and 666 are registered on the Atelier Paysan 188 map (https://www.latelierpaysan.org/Cartes-des-autoconstructeurs). And, between October 2016 and 189 March 2020, about 260 training courses have been organised across France (e.g. initiation into metal 190 work, training in building one's own implements, learning how to read technical drawings 191 (https://www.latelierpaysan.org/Formations)).

192 All the farmers engaged in the Atelier Paysan cooperative share the underlying goal, that is, meeting

193 the challenge of contributing to the free circulation of knowledge and know-how to support the 194 emergence of an agroecological agriculture. By participating, the farmers benefit from feedback from 195 other farmers, from their integration into a network of peers sharing the same values, and from the 196 support offered by the Atelier Paysan cooperative. In the rest of the article, we used the term 'farmers' 197 to refer to the farmers involved in the collective dynamic of Atelier Paysan, and the term 'R\&D actors' to refer to Atelier Paysan workers and advisors also involved in this dynamic. 


\subsection{Collecting and analysing data}

200 We used an iterative process to collect and analyse data, and we stopped the collection when we

201 obtained the same results several times and/or when the Atelier Paysan staff confirmed that the results

202 produced seemed to satisfactorily cover the field we wanted to investigate. The material analysed

203 came from various sources: (i) between May 2017 and December 2018, we conducted ten interviews

204 with two Atelier Paysan workers and one former worker; (ii) we attended public events where Atelier

205 Paysan staff presented the organisation and its work; (iii) we analysed several dozen written

206 documents, mostly internal documents, such as meeting minutes, project reports or conference papers,

207 (iv) we presented the written results of our work to two of our interviewees, and their critical eye

208 enabled us to enrich, amend and add to the analysis. Our method of data gathering and analysis, in

209 three steps related to our three angles of analysis, was as follows.

210 1) We looked at the properties of the implements that Atelier Paysan had identified or contributed to

211 designing. We characterised them in terms of what they enabled the farmer to do, how they were

212 made, in what situations, for what uses, with which material.

213 Given the very varied nature of the information available on each implement, we concentrated on 214 those of which technical drawings had been made (detailed on Atelier Paysan's website) and which

215 had been chosen for dissemination beyond their original designers. This provided us with a

216 homogenous body of documentation, and, including technical drawings that we could refer to in our

217 discussions with the Atelier Paysan workers. The data we analysed were: (i) texts and/or videos

218 accompanying each drawing; (ii) texts describing the particularities of the implements; and (iii)

219 information gleaned from our interviews with the Atelier Paysan workers. A total of 30 implements

220 were analysed using a coding method (Dumez, 2013) whereby the main properties of each implement

221 were categorised based on the following types of question: why was it designed? How was it built?

222 Who used it? In what context? A cross-analysis of the implement properties allowed us to group them

223 into five sub-categories.

224 2) We then examined the particularities of the process of equipment design assisted by Atelier Paysan, in order to understand how the equipment' specific properties emerged. Using the "Concept- 
226 Knowledge" modelling method (Hatchuel and Weil, 2009), we reconstructed the process by which

227 one particular implement was designed. This was the Buzuk crimper roller (Rolo Faca Buzuk) used

228 for growing vegetables through a cover crop mulch on permanent beds. In our retrospective analysis,

229 we sought to track the emergence of the implement's properties and what had fostered and

230 contributed to that throughout the process (e.g. a surprising state of the soil led farmers to rethink crop

231 management and the shape of the implement). We paid particular attention to "who" contributed to

232 the design of the implement. We submitted the intermediate results of our analysis separately to two

233 Atelier Paysan workers.

234 We analysed the case of the Buzuk crimper roller - the Buzuk project was initiated by Atelier Paysan and funded by the Brittany département council from 2014 to 2017 - because of the amount of written material available from various points in the process, such as meeting reports, partial accounts in articles, and the project's internal memos. We were also able to interview two Atelier Paysan workers

238 who had been involved. We asked them questions as to how the process had emerged and where; who 239 had taken part, how and why; how the implement had emerged and how its properties were gradually 240 defined; what resources were harnessed and in what circumstances; and what contributions Atelier 241 Paysan had made.

242 3) Our third step was to clarify the roles Atelier Paysan takes on to enable such design processes.

243 These may manifest through objects that are designed and disseminated (e.g. Cerf and Meynard, 244 2006; Klerkx et al., 2012), and methods that Atelier Paysan workers use to foster the process (e.g. 245 Salembier et al., 2018; Agogué et al., 2013). To that end, we used interviews and documentation analysis to: (i) categorise the objects that the Atelier Paysan workers generated and made available to farmers to design their own implements: What were these objects? How did they aim to support farmers in their activity? (e.g. hands-on training in building DIY farm equipment) ; (ii) identify the methods, such as tracking on-farm innovation, that the Atelier Paysan workers used to generate

250 knowledge and foster design processes. 


\section{4.1. The specific properties of agricultural equipment at Atelier Paysan}

253 Our study of the range of farm implements at Atelier Paysan showed that they all shared two

254 properties: they were all designed to be appropriate for particular situations (Section 4.1.1.) and they

255 were also all adaptable to situations other than the ones that gave rise to them (4.1.2.). 


\begin{tabular}{|c|c|c|c|}
\hline 苞 & $\begin{array}{l}\text { Detailed } \\
\text { properties }\end{array}$ & $\begin{array}{l}\text { Numb } \\
\text { er of } \\
\text { imple } \\
\text { ments }\end{array}$ & Quotations \\
\hline \multirow{3}{*}{ 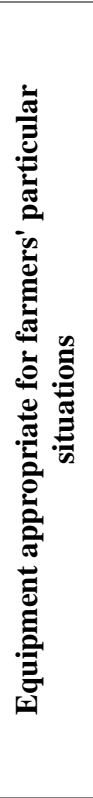 } & $\begin{array}{l}\text { Designed } \\
\text { for } \\
\text { particular } \\
\text { cropping } \\
\text { systems }\end{array}$ & $16 / 30$ & $\begin{array}{l}\text { "This weeder is designed to work as close as possible to the perfume, medicinal and } \\
\text { aromatic plants without damaging them."** } \\
\text { "[Cultibutte }] \text { It allows the work on the mounds and in permanent beds }(\ldots) \text {. It is designed } \\
\text { to shape or maintain the mounds."** } \\
\text { "[Drill roller }] \text { The drill roller is an implement for drilling through plastic mulch for sowing } \\
\text { or transplanting. This implement is very modular. It is possible to choose the number of } \\
\text { rows and the spacing between plants."** }\end{array}$ \\
\hline & $\begin{array}{l}\text { Designed } \\
\text { for working } \\
\text { in unusual } \\
\text { biophysical } \\
\text { conditions }\end{array}$ & $5 / 30$ & $\begin{array}{l}\text { "[Dahu] The two pairs of discs can be oriented independently to direct the soil where } \\
\text { necessary according to the slope and to avoid the risks of erosion. The 'boudibinage' stars } \\
\text { (which allow weeding as close as possible to the plants), are mounted on three adjustable } \\
\text { axles that allow to adapt to the topography of the terrain. The aft gauge wheel is fitted with } \\
\text { a large disc serving as a 'rudder' to keep the Dahu in the middle of the row, despite the } \\
\text { slopes and the thrust of the discs."** } \\
\text { "[Vibroplanche à étoiles] is an implement for soil refinement on permanent raised beds: it } \\
\text { prepares the soil for rolling in case of the presence of crop residues on the raised bed."** } \\
\text { "This Faca roller is adapted to the slightly sloping soils of mechanizable vineyards."*** }\end{array}$ \\
\hline & $\begin{array}{l}\text { Designed to } \\
\text { cope with } \\
\text { the } \\
\text { dynamics of } \\
\text { agro- } \\
\text { ecosystems }\end{array}$ & $12 / 30$ & $\begin{array}{l}\text { "Mobile greenhouses have two main agronomic advantages: cultivation anticipation/ } \\
\text { extension and soil regeneration. Its insertion in a cultivation plan makes it possible not to } \\
\text { overexploit a single plot under a fixed tunnel."** } \\
\text { "The articulation of the Quick hitch triangle makes it possible to optimise work (...) when } \\
\text { the micro topography is not homogeneous (bumps and hollows)."** }\end{array}$ \\
\hline \multirow{2}{*}{ 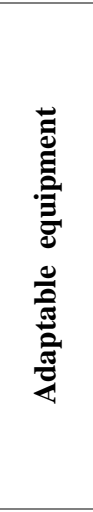 } & $\begin{array}{l}\text { Generic } \\
\text { bricks of } \\
\text { more } \\
\text { complex } \\
\text { implements }\end{array}$ & $8 / 30$ & $\begin{array}{l}\text { "[Jockey wheel with handle] This module is transposable to most agricultural implements } \\
\text { and allows adjusting the implement's working depth. Very useful on implements whose } \\
\text { height adjustment often needs to be changed."** } \\
\text { "[Tractor tool bar] Vegetable lifter, plastic lifter, weed harrow, hoeing and ridging } \\
\text { elements (...) this versatile and easy to use support allows you to equip yourself with many } \\
\text { indispensable implements at a lower cost."** } \\
\text { "[Aggrozouk] is a lightweight pedal-operated tool carrier with electric power assistance, } \\
\text { which allows light agricultural implements to be hitched in the prone position."** }\end{array}$ \\
\hline & $\begin{array}{l}\text { Implement } \\
\text { made using } \\
\text { scrap } \\
\text { materials }\end{array}$ & $30 / 30$ & $\begin{array}{l}\text { "[Market gardening hoe }] \text { The construction of this implement is very simple, two } \\
\text { wheelbarrow arms recovered from the rubbish dump, } 4 \text { small welds to attach them together } \\
\text { (...) holes to install a bicycle wheel (also from the rubbish dump), and other holes to put } \\
\text { the screws that hold the handle of the implement."* } \\
\text { "[Puncher roller }] \text { The frame can be made using scrap metal, such as old polytunnel } \\
\text { poles."** }\end{array}$ \\
\hline
\end{tabular}

257 Table 2. Specific properties of the implements designed at the Atelier Paysan cooperative, and

258 frequency of occurrence of these properties among the 30 implements studied. In the 4th column, 


\subsubsection{Appropriate equipment for farmers' particular situations}

263 In contrast with the standardisation of equipment on the market, the Atelier Paysan implements were

264 invented to enable their designers to act effectively in their particular working conditions.

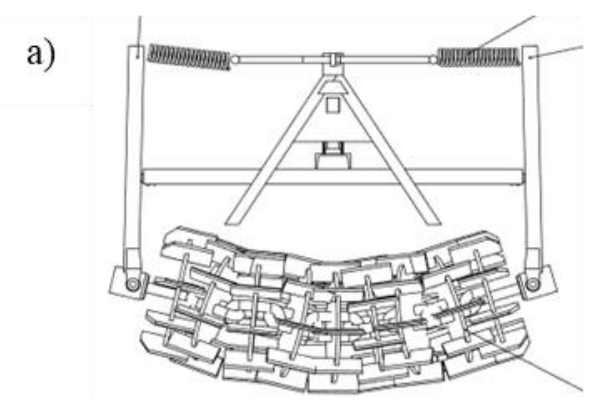

c)

265

266

267 Néo-Planet. b)

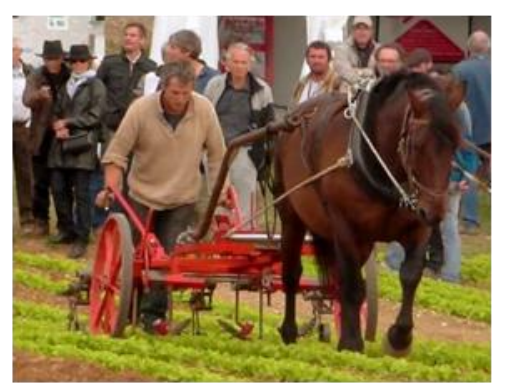

d)

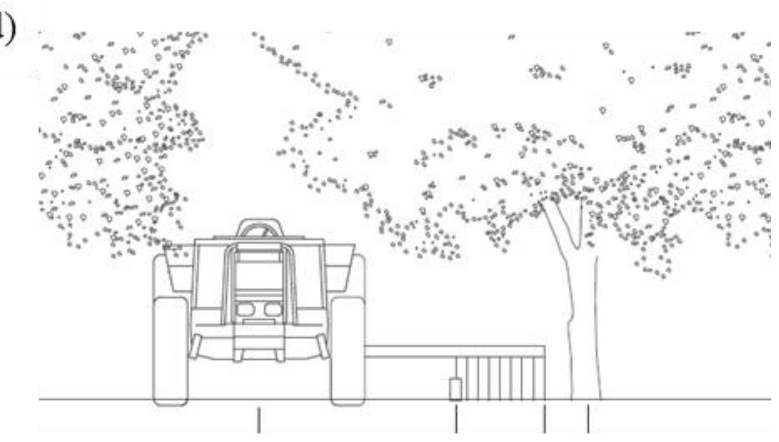

Figure 2. Pictures and drawings presenting implements appropriate to particular situations: a) a Rolofex; b) a Neo bucher; c) a movable greenhouse; and d) a Sandwich tillage implement (from https://www.latelierpaysan.org/)

a) Most implements were designed for particular cropping systems, many of which are atypical.

(i) Some of these systems involved reconfiguring layout of crops within a field, which meant changing the way the work was carried out (Table 2). One example of an atypical cropping system is agroforestry, with annual species grown in association with perennial tree crops: the Sandwich tiller was designed for easy tillage near trees (Figure 2d). Another example is permanent raised bed systems; implements designed for such systems were the Cultiridger (Culibutte) and a plastic mulch layer (to cover the soil prior to planting, thus maintaining soil moisture and preventing weed growth).

(ii) Other systems reduced the use of motorised machinery, e.g. by using animal traction. Two implements for animal-powered tillage can be cited: the Neo-Bucher (Figure 2b) and the Bineuse 
(iii) There were crop systems involving crops that are rare or unusual in France and for which special

280 implements had been designed (Table 2), such as a hoe for aromatic, medicinal and perfume crops,

281 and a tobacco hoe.

282 b) Some implements were designed for working in unusual biophysical conditions. The Dahu, for instance, was designed for hoeing vines on slopes, whereas many vineyards in France are on flat or only slightly sloping ground. Other implements were designed to adapt as they went along in response to non-uniform conditions. The Roloflex (Figure 2a) and Rolo Faca Béton, cover crop rollers for market gardening and vineyard systems, can adapt to the irregularities of uneven ground.

c) Some implements were designed to help farmers cope with the dynamics of cultivated ecosystems, which can be unpredictable, especially in pesticide-free farming (e.g. unexpected evolution of the pest pressure due to weather variations). Atelier Paysan's Serres Mobiles (Figure 2c) were greenhouses that can be moved to avoid cultivating the same piece of ground under a fixed tunnel. By moving the greenhouse, one can advance or extend the cultivation period to extend the crop rotations.

\subsubsection{Adaptable equipment}

293 All the implements are adaptable, that is, they can easily be modified for use in situations other than 294 the ones in which they emerged, whether on other farms or new situations on the original farm.

a)

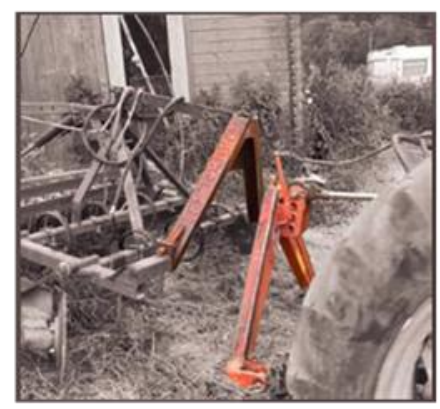

b)

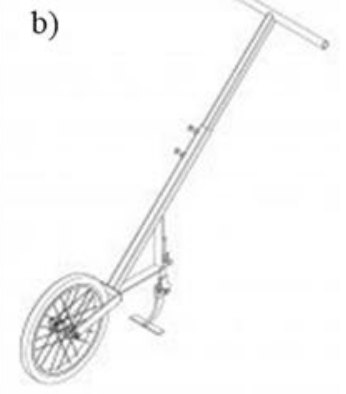

c)

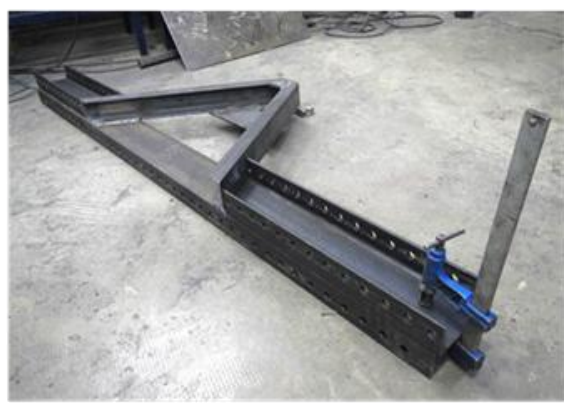

296 Figure 3. Pictures and drawings presenting adaptable implements: a) a quick hitch triangle; b) a

297 market gardening hoe; and c) a tractor tool bar (from https://www.latelierpaysan.org/)

298 a) Some of the implements designed are "generic bricks" of more complex implements (Table 2); they

299 are parts that can be appended to another implement, to add a particular function. Examples are:

300 Atelier Paysan's quick hitch triangle (the Triangle d'attelage, Figure 3a); a jockey wheel with handle 
301 (Roue de jauge à manivelle), which serves to precisely adjust tillage depth; a tractor tool bar (Figure

302 3c); and finger hoes (Etoiles de binage) that can be attached to another implement as accessories for

303 hoeing in particular places.

304 b) All the implements were designed by farmers and made using simple procedures, often from scrap materials, which cut costs and contributed to recycling (Table 2). They are easy to reproduce and

306 dismantle and a farmer can easily be trained to acquire the basic technical knowledge and skills to

307 build, maintain and repair them. These properties make them easy to adapt to new situations (e.g.

308 other farm, when facing hazards) and facilitate learning (farmers can tinker with them themselves, at

309 low cost). For example, the Rolo Faca Béton, designed for controlling vegetation between vine rows,

310 is simple and easy to make and reproduce : "Each small roller is weighted with concrete, the

311 formwork being included as an integral part of the implement. This increases the weight of each

312 roller by a third" (excerpt from Atelier Paysan's website). The market gardening hoe (Houe

313 maraîchère, Figure 3b) is made entirely from recycled materials.

314 4.2. Features of design processes: Coupled innovations, multiple designers 315 and in-situ iterative design

316 To describe specific features of the Atelier Paysan design process, we analysed the case of the Buzuk

317 crimper roller (Figure 1). We have broken down the design process into two stages.
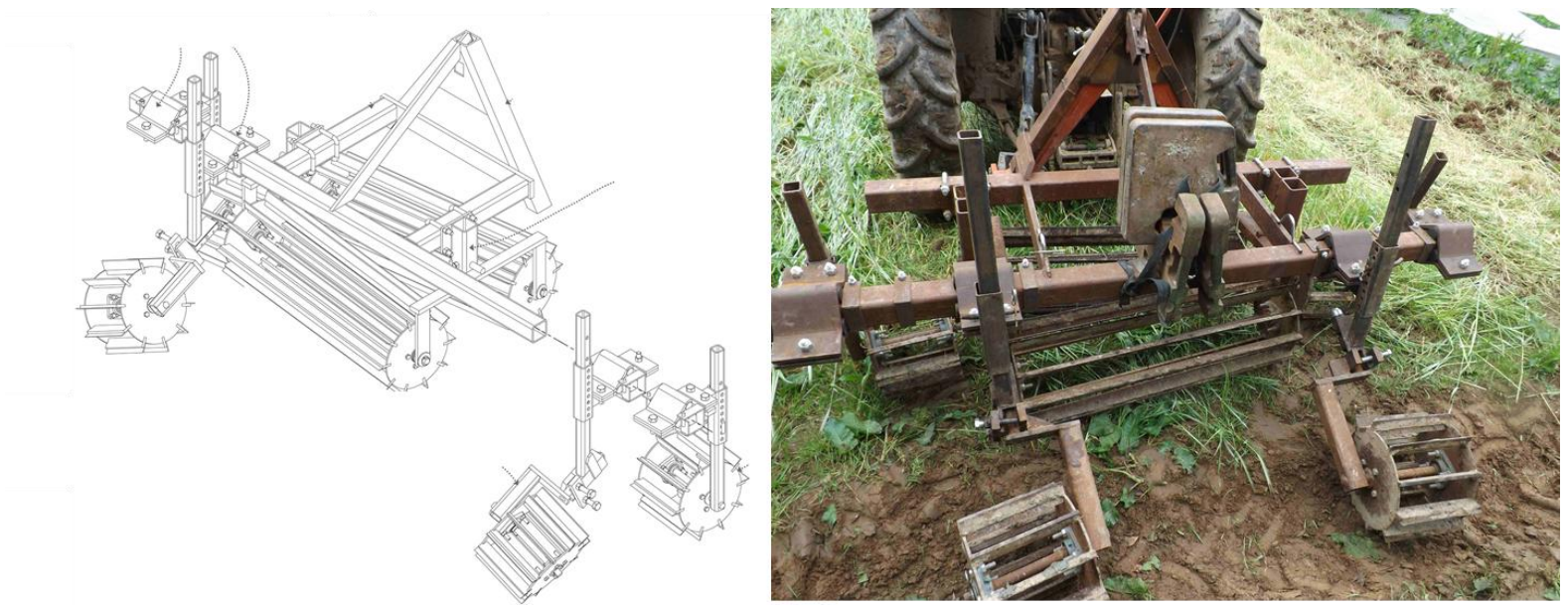

319 Figure 4. Illustrations of the Buzuk crimper roller Version 2: (a) from the technical drawing produced

320 using the SolidWorks computer-aided design software; (b) photo of the completed implement (from

321 Atelier Paysan's website). The Buzuk crimper roller consists of six rollers with chopping blades. Its 
purpose is to flatten a cover crop and break the stems, on a raised bed (top and sides of bed, and

323 alongside). The roller is effective if, after rolling, the cover crop is flattened and the next crop can be 324 sown directly.

\subsubsection{Stage 1: Elicit a design project for coupling a cropping system with an} implement

Define a common goal for a change in farming practices. The project brought together partners with complementary expertise: 7 farmers and 2 agricultural advisors, who had knowledge of local agricultural conditions and could explain design expectations at the level of each farm and the region, and Atelier Paysan workers, who had expertise in agricultural equipment engineering (e.g. computer modelling, equipment construction). Trades and competencies guided the allocation of some tasks during the process, for instance, technical drawings were made by the Atelier Paysan workers, and the farmers did the more manual fieldwork. But all decisions and assessments were discussed collectively. From the start of the project, the partners were in agreement on the following objectives: (i) vegetable growing; (ii) exploring ways to maintain soil fertility; and (iii) reducing the time spent on crop husbandry tasks and the need for inputs (fuel, plastic mulch). To stimulate their explorations, the partners organised an information watch. Very soon, in connection with various initiatives the partners knew about (e.g. a raised bed project Atelier Paysan was involved in; experiments by the Maraichage sur Sols Vivants association), the collective was drawn to the concepts of "vegetable growing on living soil", "conservation farming" and "seeding through a cover crop mulch". In light of their various skills, preferences and aims, the partners gradually narrowed their exploration to a combination of a cropping system and implements that would enable farmers to: (i) sow a cover crop requiring little tillage; (ii) sow the next crop directly through a mulch formed by the killed cover crop; and, for some of the farmers, (iii) use permanent raised beds.

Make a preliminary definition of a desirable cropping system. The collective had few references for the three techniques (introducing a cover crop, direct sowing, permanent raised beds) and how to combine them for vegetable cropping in their local region (Finistère, Brittany). The partners were

348 familiar with the agronomic processes concerned - e.g. direct sowing fosters the biological life of the 
soil - but they asked themselves, for each farm's situation, "What varieties that grow well in Finistère

350 can be used in the cover crop mix? What Plan B could we use if the cover crop fails to grow? How

351 can we manage a cover crop on permanent raised beds, depending on the season? What implements

352 should we use for direct sowing of the main crop? How does the choice of cover crop affect the direct

353 sowing and growth of the main crop? What are the risks?", and so on. The collective explorations and

354 the acquisition of new knowledge resulted in the formulation of some general choices for crop

355 management and for including a cover crop in the rotation, on which all the farmers were in

356 agreement (e.g. varieties sown, dates, technical operations).

Make a preliminary definition of a desirable implement. Whenever they discussed a crop management task, the partners asked themselves what implements already existed for the job. Very soon they realised there was no implement for flattening a cover crop on raised beds so that the main crop can be sown directly. They noted the specifications of the crimper roller, which already existed for open field systems with grain or oil crops. This implement consists of a central roller to which are welded horizontal blades; it flattens and crimps the vegetation, so that it will wither and die on the ground. The collective's challenge was to make sure the cover crop was sufficiently damaged to remain lying on the raised bed, covering the soil and preventing weed growth in the main crop. Several options were considered when it came to imagining the new implement, which they called the Buzuk crimper roller. The Atelier Paysan workers transformed the ideas collectively explored into technical drawings (Figure 4). These drawings were amended each time a modification of the implement was proposed. Prototypes of the implement were made at collective working sessions, with assistance from Atelier Paysan. There was a new working session every time the implement had to be modified. The farmers were thus able to familiarise themselves with implement building operations and could acquire skills to be autonomous in their repair and re-design. "The major difficulty with the Faca roller is encountered on the sides of the permanent raised beds. (...) Fixed rollers pass on the top of the permanent bed. Of the 2 options considered, the one with the small roller in the centre is preferred, for its better balance. (...) When discussing this with Joseph this morning, we thought that 
376 the systems, sometimes used with Cress fingers, using rubber (...) Let's see after tests if there are risks

377 of jamming in the axes of the rollers" (from a Buzuk project report). But once the implement had been

378 made, there were still many unknowns as to how it would behave in different situations, and in

379 interaction with the imagined cropping system (crop species, sowing dates, farmers' expectations

380 etc.).

381 4.2.3. Stage 2 - Continue the design of the "cropping system - implement" 382 combination during trials on different farms

383 The next step - involving all the partners - was to continue collective design of the implement and the

384 cropping system during trials in farmers' fields, observing, interpreting and assessing interactions

385 between the prototype of the implement, field conditions and the cropping systems.

386 These trials were run in a variety of field conditions, such as clayey or loam soils, different previous

387 crops, different crops after the cover crop. Their implementation was always monitored by several

388 partners who gradually acquired some indicators which helped (a) to trigger technical operations and

389 follow their implementation (e.g. in what soil conditions is it best to use the implement?) and (b) to

390 assess the results the farmers were seeking after rolling, that would cause them to deem the operation

391 successful. Figure 5 shows that these indicators enabled the design process of coupled innovation of

392 implements and cropping systems to advance. 


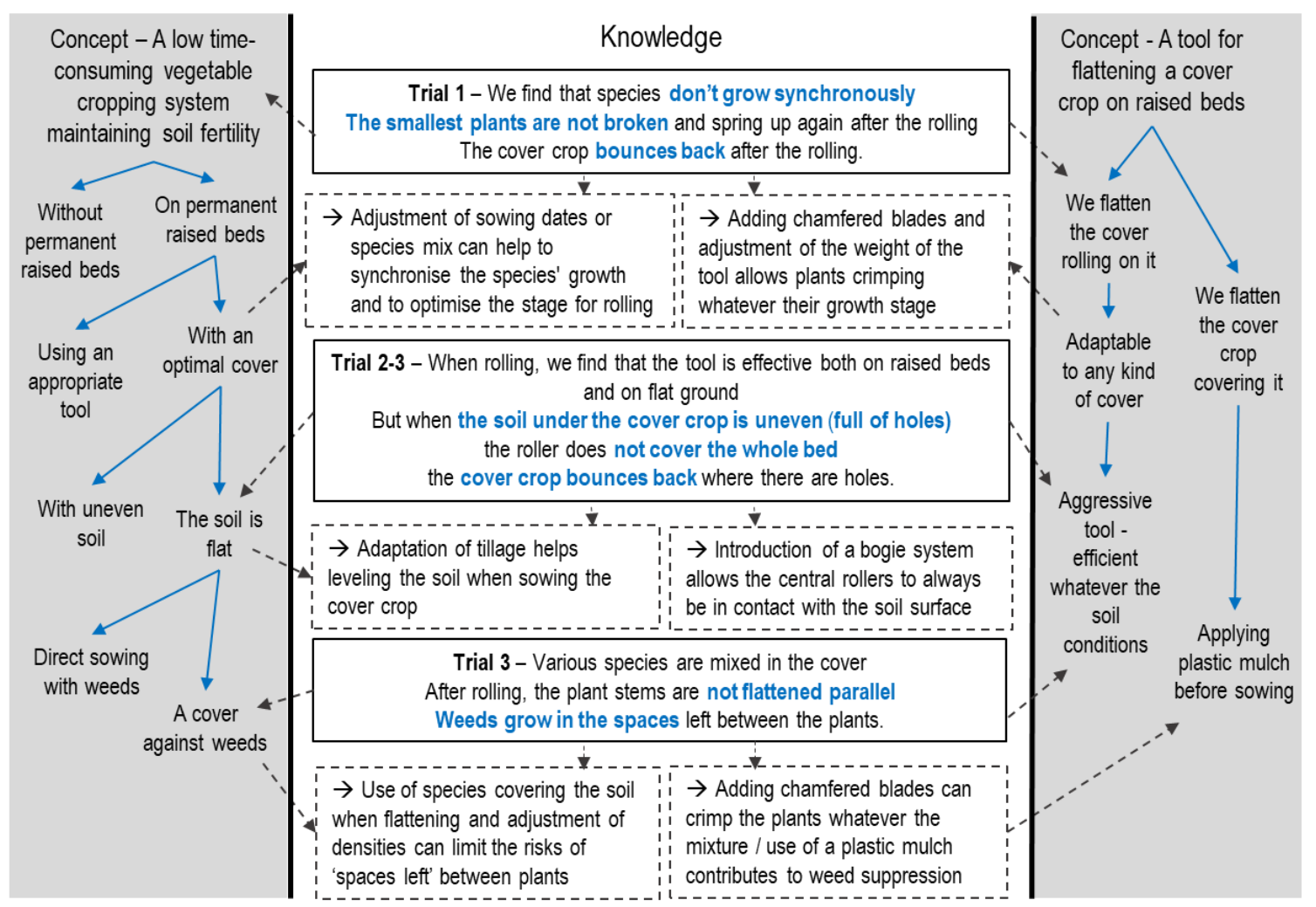

394 Figure 5. CK model illustrating joint emergence of an implement and a cropping system, designed by

395 the collective involved in the Buzuk project, and detailing different situations during trials in farmers'

396 fields. Left and right of the figure (grey rectangles) are the concepts spaces where we observe the

397 gradual definition (blue arrows) of the "implement" concept (right) and "cropping system" concept

398 (left), in connection with the information acquired on the agroecosystem during trials. In the central

399 space, the knowledge produced in the trials, and which stimulated the design of the two objects, is

400 described. In this space, the rectangles refer to the indicators collected during the experiment and that

401 foster the exploration of knowledge on new design proposals (dotted rectangles). The temporality of

402 the design process goes from top to bottom in the figure. Blue bold type in the central space refers to

403 the indicators. The dotted arrows show the interactions between knowledge and concepts throughout

404 the process.

a) Acquiring indicators to trigger technical operations and follow their implementation

406 Whatever the species in the mix - such as rye/vetch, crimson clover, sorghum, radish, forage pea - the 407 implement prototype successfully flattened the vegetation several times. One major difficulty was to 408 achieve a mix in which all the species grew synchronously; otherwise, rolling would be less effective 
because the stems of the smallest plants would not be damaged and they would spring up again. This

410 observation led farmers to look for 'optimal covers for rolling' and caused some of them to stop using

411 vetch in their mix, as its behaviour was too unpredictable.

412 Field trials and observations also confirmed that the implement could be used effectively on raised

413 beds as well as flat ground - in both cases the cover crop did not come up - so validating the design

414 elements introduced for that purpose.

415 A levelled soil quickly proved to be a determining factor for the implement's effectiveness. In several

416 field trials it was found that the soil under the cover crops was "irregular, not flat" or "had ruts", or

417 "the central roller was not working the whole bed", "the cover crop stood up again, or there were

418 holes" (from a Buzuk project report). In view of these problems, the collective considered possible

419 action to take before applying the roller, such as tillage to level the soil when sowing the cover crop,

420 or altering the implement's design to adapt it to such situations, for example "Installation of a bogie

421 system for fixing the central rollers: articulated joints allow the two central rollers to always be in

422 contact with the soil surface, whatever the angle of the implement's chassis" (from a Buzuk project

423 report).

424 The group's representation of what the ideal state of the cover crop would be for applying the roller 425 was refined over the course of the trials. The height, composition, density, growth stage and so on of 426 each variety all played a part. To maximise chances of choosing the right cover crop, the collective 427 thought about adjusting the sowing date and the rolling date: "Season by season we delayed rolling 428 the rye a little more; we realised clearly that June was the most effective time" (from a Buzuk project report). They also considered making the implement more "aggressive"; in the end they added

430 chamfered blades that crimped the plants more efficiently, whatever their growth stage.

\section{1 b) Acquiring indicators to assess the results after rolling}

432 The trials showed that after the cover crop had been flattened and crimped, there were areas of bare 433 soil, not covered by the flattened crop, where weeds could grow. This led the group to reconsider the 434 sowing density and to choose combinations of species that covered the ground better once flattened. 435 They found that some species that produce a lot of aerial biomass did not cover the ground well once 
436 flattened (e.g. sunflower). Unforeseen events like the lodging of some varieties also favoured weed

437 growth: after the roller had passed, the plant stems were not lying parallel but were leaving spaces

438 where weeds could grow. These observations led the collective to consider, in some situations,

439 applying more classic methods after passing the roller, such as laying plastic mulch before sowing the

440 vegetable crop to limit competition, or making better use of complementarity between species in the

441 cover crop mix.

442 This section on results highlights three features of the design processes that helped to make the 443 implements appropriate and adaptable: (i) over the course of the process, the implement was designed 444 simultaneously with, and in keeping with, the cropping system (design of a 'implement-cropping 445 system' combination), and the process took place over time, by testing prototypes in a range of 446 agricultural situations; (ii) new resources for change were also generated (e.g. technical drawings of 447 the implement); and (iii) during the process, the farmers and the R\&D actors involved, including 448 Atelier Paysan staff, acted together as designers with complementary skills.

\subsection{Roles taken on by the R\&D structure in the design process}

We identified three roles that Atelier Paysan took on to support farm equipment design processes.

\begin{tabular}{|c|c|c|}
\hline Roles & $\begin{array}{l}\text { Actions performed to } \\
\text { fulfil these roles }\end{array}$ & e \\
\hline \multirow{3}{*}{$\begin{array}{l}\text { Organising } \\
\text { the sharing } \\
\text { of on-farm } \\
\text { equipment } \\
\text { design } \\
\text { experiences }\end{array}$} & $\begin{array}{l}\text { To offer the possibility } \\
\text { for farmers to contribute } \\
\text { and enrich the common } \\
\text { knowledge pool by } \\
\text { sharing the fruit of their } \\
\text { own implement design } \\
\text { processes }\end{array}$ & $\begin{array}{l}\text { "We identify and document inventions and adaptations of equipment created by farmers who have } \\
\text { not waited for ready-made solutions from experts or industry, but have invented or tweaked their } \\
\text { own machinery. We seek to promote these farmer-driven innovations."*** "The forum is the } \\
\text { collective draft of the structure, there to inspire and be inspired without being definitive. We put } \\
\text { everything we find in it, we describe as much as possible to put things in context and describe the } \\
\text { design process if we want to take things back."* }\end{array}$ \\
\hline & $\begin{array}{l}\text { To track and inventory } \\
\text { equipment designed by } \\
\text { farmers }\end{array}$ & $\begin{array}{l}\text { "Farmer-led initiatives are gathered by our team and compiled into technical factsheets with photos, } \\
\text { videos and testimonies documenting the equipment developed by farmers. More than } 500 \text { technical } \\
\text { factsheets have already been compiled."*** "It is a census of everything that can exist on farms, in } \\
\text { terms of DIY equipment, it is thematic or geographical. When I arrived there was a tour in Alsace, } \\
\text { in Brittany and Pays de la Loire, we called everybody, all the organisations we work with and we } \\
\text { told them we were there, looking for farmers."* }\end{array}$ \\
\hline & $\begin{array}{l}\text { To support equipment } \\
\text { design processes on } \\
\text { farm }\end{array}$ & $\begin{array}{l}\text { "We are also equipped to support and assist working groups that wish to develop equipment } \\
\text { adapted to their agricultural practices. Together, we compile a specification sheet for the equipment } \\
\text { we want to create. Our staff produce a draft design which is then corrected by the working group. } \\
\text { After a number of rounds of feedback and responses, we begin prototyping. Depending on the } \\
\text { equipment, prototyping can involve a training course where the group can learn or build on their } \\
\text { metal working skills. The prototype is then tested on farms and continues to evolve. Once the } \\
\text { group has reached a consensus on a design, Atelier Paysan can produce open source technical } \\
\text { drawing and begin to disseminate the equipment through workshops and training courses."*** }\end{array}$ \\
\hline
\end{tabular}




\begin{tabular}{|c|c|c|}
\hline \multirow{2}{*}{$\begin{array}{l}\text { Making } \\
\text { available a } \\
\text { pool of } \\
\text { resources } \\
\text { to stimulate } \\
\text { on-farm } \\
\text { equipment } \\
\text { design }\end{array}$} & $\begin{array}{l}\text { To stimulate design by } \\
\text { making available written } \\
\text { material and videos }\end{array}$ & $\begin{array}{l}\text { "Information tailored to the needs of small-scale farmers: forum posts, articles, designs, tutorials } \\
\text { and our DIY guide. The technologies and practices we have developed through farmer-led } \\
\text { research and development are freely accessible through articles, designs and tutorials, on our } \\
\text { website. We would like to create an open source encyclopaedia, where people can freely } \\
\text { contribute and make use of available resources. We believe that farming skills are common goods, } \\
\text { which should be freely disseminated and adapted."*** "There are the plans and tutorials which are } \\
\text { the heart of this knowledge dissemination, with for each one a small article, and then links to the } \\
\text { various articles of the forum and the necessary bibliography. And then, there is the index of the } \\
\text { resources, the thematic index which makes it possible to search on the site and on the forum"* }\end{array}$ \\
\hline & $\begin{array}{l}\text { To stimulate design by } \\
\text { doing }\end{array}$ & $\begin{array}{l}\text { "We provide training courses for farmers to learn to make their own implements. In the course of } 3 \\
\text { to } 5 \text { days, agricultural implements are created in the workshop which are either non-existent on the } \\
\text { marketplace, too costly or not adapted to small-scale organic farming. As well as building an } \\
\text { implement, farmers gain in autonomy as they learn metal work. A farmer who has built rather than } \\
\text { bought his/her implements is better placed to repair or adapt it in future." *** "During experiments, } \\
\text { the farmers use the implement and make them evolve, supported by the technical team."* }\end{array}$ \\
\hline \multirow{2}{*}{$\begin{array}{l}\text { Linking up } \\
\text { equipment } \\
\text { designers } \\
\text { scattered } \\
\text { around the } \\
\text { country }\end{array}$} & $\begin{array}{l}\text { To structure its work } \\
\text { around a shared } \\
\text { vision/project for a new } \\
\text { form of agriculture }\end{array}$ & $\begin{array}{l}\text { "The collective knowledge developed within the Atelier Paysan cooperative is a common good for } \\
\text { agriculture, freely circulating and modifiable. No patents! We publish it under a free Creative } \\
\text { Commons license. (...) Open source is also supposed to accelerate contributions. As everything is } \\
\text { open, there is no barrier to get involved in the evolution of equipment."** }\end{array}$ \\
\hline & $\begin{array}{l}\text { To animate and make } \\
\text { known a network of } \\
\text { geographically scattered } \\
\text { designers }\end{array}$ & $\begin{array}{l}\text { "The idea is to make the dynamics apparent by explaining what we do. There are still people who } \\
\text { have a partial vision of what we do, there is a whole job of explaining our activities (...) generally I } \\
\text { criss-cross the territory, I make calls, I send emails, I go there, we exchange with the facilitators, } \\
\text { administrators (...) there are quite a few new territories that have been added, the east, the south- } \\
\text { west, a bit of PACA, people with whom we didn't work much and who are now entering the } \\
\text { dynamic."* }\end{array}$ \\
\hline
\end{tabular}

452 Table 3. Roles taken on by the Atelier Paysan workers to support farm equipment design processes.

453 The quotations are drawn from interviews $(*)$, Atelier Paysan working documents $(* *)$ and internet

454 website $(* * *)$.

455 4.3.1. Role 1 - Organising the sharing of on-farm equipment design 456 experiences

457 Atelier Paysan has organised itself to centralise and enrich a common pool of knowledge and know-

458 how about farmer-built equipment for agroecology (Table 1). This was done under a Creative

459 Commons license (CC-By-NC-SA 3.0), on the Web platform particularly. To feed into this common

460 pool, Atelier Paysan combined three ways of sharing on-farm equipment design experiences:

461 1/ Atelier Paysan offered the possibility for farmers to contribute and enrich the common knowledge

462 pool by sharing the fruit of their own implement design processes. Farmers who had designed an

463 implement shared what they have learnt either on the Web platform's free-access forum (Figure 6) or

464 by contacting Atelier Paysan. 

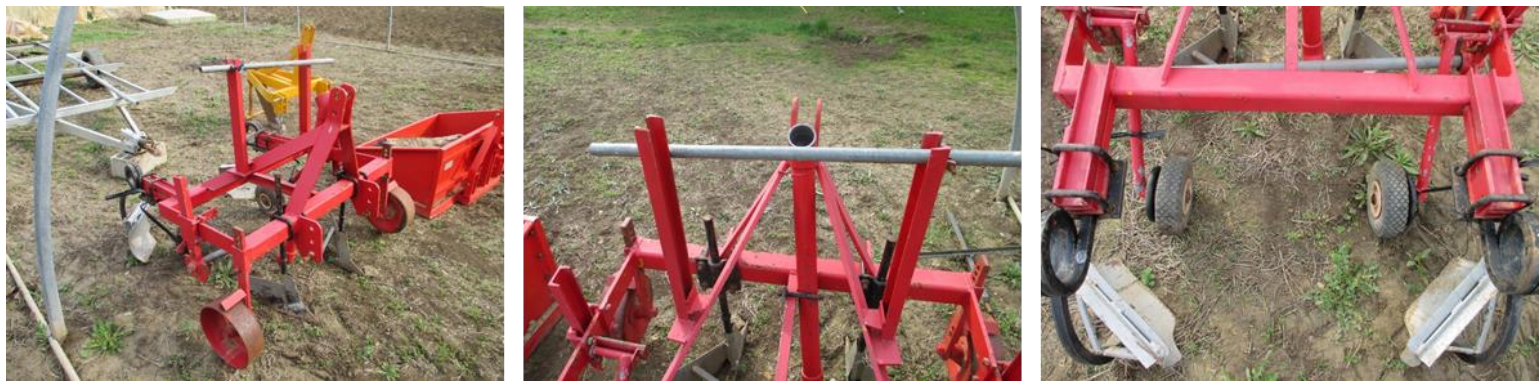

Figure 6. Picture of an implement designed on farm and shared on the forum with a farmer's testimony: "This is my plastic mulch layer on a mini-cultivator base ... it lays $1 m$ wide plastic film with drip irrigation under the mulch [...] I spent about two days on it, but thinking it out took much longer than that! I decided to build this plastic mulch layer because I couldn't find a second-hand one. As to price, it's all salvaged scrap [...] gas bottles, a piece of an electricity pole, weight lifting bars found on a waste tip, [...] all I had to pay for was welding rods, two wheelbarrow wheels and the paint."

2/ Another method used by Atelier Paysan was to track and inventory implements designed by farmers. This sometimes involved systematic tracking, that is, searches organised in a particular area to map farmers who had designed equipment falling within the scope of investigation: "Farmer-built equipment intended for use in agriculture, useful for small-scale (...) agroecology (...) built with an easily-accessible level of technical know-how, and not patented" (Atelier Paysan, 2017). Sometimes the searches focused on one theme, looking for a particular equipment concept. For example, a hunt for a tube seeder for market gardens was launched, to explore the types of seeder being used on market gardens (e.g. PVC structure, adjustable handle), their uses (e.g. sowing, applying fertiliser) and the situations in which farmer-designed tube seeders were being used. These searches produced a roundup of the state of the art regarding particular equipment concepts, revealing a variety of designs from which farmers could choose according to their characteristics.

484 3/ In supporting equipment design processes, Atelier Paysan also investigated new equipment suitable 485 for local situations and built on the knowledge fed into the common pool. 

equipment design

488 Since its creation, Atelier Paysan has gradually built up a large body of equipment design resources to support the technological autonomy of farmers with different skills and projects, "The gaps and flaws in the system are identified as we go along, the holes that need to be plugged..." (From an interview 29/05/2017).

a) Stimulating design by making available written material and videos

One kind of resource is written materials and videos. The most emblematic of these are:

Testimonies. For each implement inventoried, a written testimony was posted, open-access, on Atelier Paysan's website. These testimonies might be written by the farmer or by an R\&D actor: the idea was to share the knowledge of a new implement in the context in which it was designed, to serve as a source of inspiration and to prompt discussion on the Atelier Paysan forum (Table 1). Every designer of an implement inventoried by Atelier Paysan featured on a map of France's "farmerdesigners", enabling anyone who wanted to know more about an implement to contact its designer.

Implement technical drawings were another type of resource that Atelier Paysan created and shared, based on what they had learnt from farmers' equipment-building activities. Atelier Paysan produced technical drawings: (i) if a group of farmers expressed interest in an implement that existed on a farm; or (ii) if Atelier Paysan was supporting an equipment design process (e.g. for the Buzuk crimper roller). Making the decontextualised equipment technical drawings from what was known about an implement on a farm required additional information, such as technical analysis of the implement's engineering design or a state of the art on implements with similar properties. Several criteria had to be met: (i) the technical drawings had to be usable by individual farmers and in training sessions for

508 building DIY farm equipment; (ii) the implements had to be reproducible using materials available on 509 the market; (iii) from an agronomic point of view, the implement as shown in the technical drawings

510 had to be at least as effective as the original implement; (iv) the cost of building it had to be 511 affordable; and (v) it had to be reproducible with basic and easily obtainable metalworking tools (e.g. 512 drill, grinder, arc welding unit). The drawings gave 3D views of the implements, produced using 
513 CAD software. Many of the drawings were accompanied by videos presenting the implement and

514 showing it in operation.

515 Testimonies and technical drawings were intended to enrich the pool of knowledge available on designing a new implement. To help users find their way around the pool of information on the Web platform, Atelier Paysan structured the knowledge in several ways, classifying each implement as

518 follows: (i) by the cropping technique it could be used for, as for instance, a listing for cover crops,

519 for biodynamic agriculture; (ii) by the degree of general applicability of the knowledge offered :

520 testimonies on the forum versus de-contextualised drawings on a tab on the website; or, sometimes,

521 (iii) by the implement prototype's degree of testing, for example technical drawings of several versions of the implement - some marked "R\&D in progress" - and a progression in the testimonies.

\section{b) Stimulating design by doing}

Atelier Paysan offers help to farmers for experimenting with equipment design, enabling them to learn by doing it themselves. We found (Table 3) that this help took the form of: (i) a wide range of training sessions: training in designing and building equipment, or in reading technical drawings, etc.; and (ii) monitoring farmers' experiments on their own farms during the design of an implement or its adaptation to their particular situation.

\subsubsection{Role 3 - Linking up equipment farmer-designers scattered across the} country

531 Atelier Paysan structures its work around the vision of a new form of agriculture, replacing dominant design representations with "small-scale organic farming", "farmer-built equipment" and "openaccess equipment and knowledge" (statutes of the Atelier Paysan cooperative). By expressing and sharing this ambition, they aim to bring together the scattered community of farmer-designers across the country. Their ambition for change is open: it does not focus a priori on types of equipment, cropping systems or farm situations. We noted that the definition of this goal is dynamic, progressively refined over time, mainly in connection with: (i) exploration of new equipment (e.g. the exploration, historically centred around market gardening implements, now covers implements for arable crops, vineyards and orchards); (ii) more partnerships, for instance, the partnership with the 
540 non-profit organisation Demeter enabled Atelier Paysan to explore such concepts as "equipment for

541 biodynamic agriculture"; and (iii) the increasing number of skills among the collectives involved (e.g.

542 from low-tech equipment to the use of software in equipment design).

543 The evolution of this shared project is based on Atelier Paysan's nationwide facilitation work. Its

544 innovation tracking, national events, map of farmer-designers and participation in seminars have

545 made the cooperative well known, stimulated communication within the community, drawn attention

546 to the cooperative's projects and initiated discussion about them in various collectives.

\section{Discussion}

548 We have organised this discussion around two themes. In Section 5.1. we discuss features of

549 processes for designing appropriate and adaptable equipment for agroecology; then in Section 5.2. we

550 discuss the implications of considering farmers as designers in design processes involving R\&D.

\subsection{Designing appropriate and adaptable equipment for agroecology: coupled}

552 innovation processes

553 Our findings suggest some avenues for research to stimulate the design of agricultural equipment that contrasts with the dominant design. Appropriateness and adaptability are often mentioned in connection with the challenges of shifting to new agricultural systems (Vo $\beta$ et al., 2007; Dedieu et al., 2008; Darnhofer et al., 2010; Brédart and Stassart, 2017) but rarely, as far as we know, regarding equipment design. The only references we found are works dealing with 'appropriate technologies' (e.g. Jolly et al., 2016). The notion of autonomy at the Atelier Paysan contrasts with the "autonomy" sought in the dominant design, where the main idea is to reduce the brainwork required of farmers, as some mental tasks are performed by the machinery instead (e.g. Relf-Eckstein et al., 2019). Whereas in the dominant design, farmers choose from a range of equipment and settings offered to them, in the case of Atelier Paysan, they participate directly in the design of the equipment and not only in its adjustment. They thus contribute to defining the equipment's properties, according to their own

564 situations and expectations. The properties of the equipment are not known at the beginning of the

565 design but are gradually discovered as the design of the equipment and the cropping system 566 progresses. 
567 One major result of our work is to show that equipment for agroecology emerges from coupled

568 innovation design processes, a concept which was introduced by Meynard et al. (2017) in a discussion

569 about coordinating innovations between cropping systems and food processing. We propose to extend

570 the use of this concept to the design of 'cropping systems' and 'inputs', such as equipment, but also

571 varieties, biocides, etc. In other word, this concept allows us to question the historical separation of

572 input design (e.g. by agro-industry) and cropping system design (by farmers, sometimes supported by

573 advisors), and to organise their joint emergence on farms by considering farmers as designers of both

574 objects. Thus, regarding the equipment as an object to be designed, rather than a contingent variable,

575 offers farmers new opportunities for designing in situ. For example, finding that it was necessary to

576 level the soil, the designers were able to think of acting simultaneously on the cropping system, by

577 adding a tillage operation at the appropriate moment, and on the equipment, by adding a bogie

578 system. However, designing equipment and cropping systems in tandem raises research questions that

579 could only be addressed if agronomists and the few researchers working on equipment worked

580 together. Until now there had been little collaboration between the two (Piovan, 2018; Guillou, 2013).

581 We show also that these coupled innovation design processes - and the emergence of appropriateness and adaptability of equipment - are constructed in the course of action, in situ. This finding ties up with a feature of the design processes described by Schön (1983), when he wrote of the dialogues designers set up, in the course of their work, between emerging objects and the situational dynamic.

585 We show how designing through action in in-situ experiments can help someone "manage the exploration of an unknown space" in a situation where: (i) one has little knowledge and faces uncertainties (as with the Buzuk crimper roller); and (ii) one wants the equipment to be adapted to

588 farmers' expectations and particular situations. The case of the Buzuk crimper roller shows that it is in the course of practical action, and by testing in new situations, that systemic representations of objects

590 gradually emerge. Our findings highlight an original feature of such a process: these systemic

591 representations serve both for the gradual definition of equipment and cropping systems suited to

592 farmers' situations and expectations, and for the emergence of new resources for change that Atelier

593 Paysan will disseminate, such as technical drawings of the implement. The literature sometimes 
594 points to the co-emergence of cropping systems and resources for change (e.g. design briefs, scale

595 models, visualisations, Klerkx et al., 2012), and our findings contribute to highlighting how this

596 process unfolds. More precisely, the results show that it is in action, in a real situation, by observing

597 and interpreting what is going on, that designers can establish systemic links: they identify

598 interactions between the equipment, the cropping system and processes in the agroecosystem. They

599 can then judge the choices they have made. And this will sometimes lead them to consider other

600 actions: e.g. if they deem the result to be undesirable, they may want to change the cover crop.

601 Lastly, we show that the emergence of systemic representations - supporting the coupled innovation

602 design processes - are contingent on the use of indicators which help to trigger technical operations,

603 to follow their implementation, and to assess the results the farmers are seeking. These indicators are

604 consistent with those described by other authors: e.g. "indicators used by managers when trying to

605 integrate ecological systems and production-oriented activities" (Girard et al., 2014); or "indicators

606 used by farmers to design agricultural systems" (Toffolini et al., 2016). In our study, we show that

607 these indicators play a central role in the construction of systemic representations of different objects;

608 they enable the designer to manage uncertainties, and to establish links between the cropping system,

609 the equipment, its behaviour and the dynamics of the agro-ecosystem, and to evaluate the success of

610 the "equipment-cropping system" combination. A challenge would be to find ways to capitalise on

611 these indicators and on these systemic representations, and thus to support the design of equipment

612 and cropping systems in other situations.

\section{5.2. Supporting farmer-designers}

614 This study sheds light on some implications of design processes involving R\&D and in which farmers

615 are regarded as "designers". Unlike the dominant design model, where equipment is designed off-farm

616 by industrial firms that distribute them with a user's manual, Atelier Paysan sets out to help farmers

617 design their own equipment. 'How to support farmer-designers' is an emerging research field (e.g.

618 Chizallet et al., 2019); until recently farmers were mainly considered as appliers, deciders or

619 optimisers (Salembier et al., 2018). 
$6201 /$ One contribution of this work is to revise the figure of the "user" in design processes. The literature

621 on relations between $R \& D$ and farmers in a design situation more or less explicitly regards farmers as

622 users of the "object" to be designed. Either: (i) they are the end-users of something generated 623 upstream by R\&D (top-down dissemination), or (ii) they are end-users but R\&D involves them so as 624 to take their needs and demands into account (e.g. Bellon and Huyghe, 2017), or (iii) they are users of 625 objects generated by R\&D, but continue to redesign them once they have adopted them (continuous 626 design in use, Cerf et al., 2012). In the approach we spotlight here, the farmers and the R\&D actors 627 are both designers and users: together they generate new equipment, new technical systems and new 628 resources for change and, to do so, they use the technical drawings, the prototypes of the future 629 equipment, the observations made in the fields, and so on. The process thus involves multiple 630 designers, with each one's work feeding and fertilising the work of the others.

631 2/ Another contribution concerns the way R\&D can support farmer-designers. First, we show that it 632 implies the opening of new channels for the circulation of knowledge and know-how, so that what is 633 generated by some farmer-designers can be used by others. This can be done by opening new spaces 634 of exchange (e.g. Atelier Paysan forum), by centralising and capitalising on knowledge scattered 635 around the country (e.g. internet platform), and by using appropriate knowledge production methods 636 (e.g. tracking on-farm innovations). Such pooling depends on the free circulation of knowledge and 637 know-how, allowed by the Creative Common licence at the Atelier Paysan (Chance and Meyer, 638 2017), and on the Atelier Paysan network facilitation work (e.g. Kilelu et al., 2013) to link up farmer639 designers working on their own here and there around the country. Considering farmers as designers 640 also implies updating the nature of resources designed by R\&D, which used to be decision support 641 systems, rules for action, etc. We see that the Atelier Paysan resources have been designed to equip 642 different 'moments' of design processes (Hatchuel et Weil, 2009; Schön, 1983), such as training for 643 learning by doing, supporting generative on-farm trials, or furnishing skills that farmers are lacking 644 (e.g. on equipment modelling). These resources have also been designed to support the empowerment 645 of farmers in the design of their own equipment, so that they can enrich the common pool of 646 knowledge on new equipment, and in turn accompany other farmers in the design of their equipment 
647 locally. The traits of this organisation refers to characteristics of open innovation processes

648 (Chesbrough et al., 2014), conducive to agroecological principles (Prost et al., 2016; Berthet et al., 649 2018).

\section{6. Conclusion}

651 This research has explored equipment that could be suitable for agroecology, and the ways in which

652 such equipment are designed that differ from those of the dominant design model. Our study of the

653 work of Atelier Paysan highlights two desirable properties for farm equipment: appropriateness and 654 adaptability. These properties are very different from those of the dominant design, and in line with 655 principles associated to agroecology, such as taking account of ecological and social uncertainties and 656 of the diversity of situations. The study also sheds light on features of design processes in which such 657 equipment can emerge: they are designed on-farm, by or with farmer-designers, at the same time as 658 the cropping systems they are to be used for. They emerge from coupled innovation design processes 659 that take place during their application on the farm. Results also show that both farmers and R\&D 660 actors are designers of the equipment, the cropping systems, and resources for the design process, to 661 which they all contribute: by sharing past experiences, by bringing together farmers, by producing 662 technical drawings, etc. We also shed light on three roles taken on by the R\&D actors to foster the on663 farm design of equipment: organising the sharing of on-farm equipment design experiences, making 664 available a pool of resources to stimulate on-farm equipment design, and linking up equipment 665 designers scattered around the country. Atelier Paysan's approach to farm equipment design offers an 666 alternative to the dominant design, but such processes depend on active commitment by farmers and 667 investment (training, time), which not all farmers can make and for which no support is available yet. 668 These results open the avenues for further research on designing coupled innovations and on 669 supporting farmer-designers, in and beyond the farm equipment sector.

\section{Acknowledgments}

671 This work was supported by the Science for Action and Development (SAD) division of INRA and 672 the French Environment and Energy Management Agency (ADEME). It was carried out under the 673 umbrella of the Initiative for Design in Agrifood Systems (IDEAS). The work benefited from rich 
674 exchanges with Vincent Bratzlawsky, whom we gratefully thank for his rich testimony on the Buzuk

675 Project. We are furthermore deeply grateful to the two anonymous reviewers, their very rich and

676 constructive feedbacks helped us to improve the article. We also thank Harriet Coleman and Liz

677 Libbrecht for the English revision of this paper.

\section{References}

679 Agogue, M., Yström, A., Le Masson, P., 2013. Rethinking the Role of Intermediaries As an Architect 680 of Collective Exploration and Creation of Knowledge in Open Innovation. Int. J. Innov. Manag. 17, 681 1350007. doi:10.1142/S1363919613500072

682 Altieri, M.A., 2002. Agroecology: The science of natural resource management for poor farmers in 683 marginal environments. Agric. Ecosyst. Environ. 93, 1-24. doi:10.1016/S0167-8809(02)00085-3

684 Atelier Paysan website : https://www.latelierpaysan.org/

685 Atelier Paysan, 2017. Proposition d'un guide méthodologique pour les tournées de recensement 686 d'innovation paysannes.

687 Bellon Maurel, V., Huyghe, C., 2017. Putting agricultural equipment and digital technologies at the 688 cutting edge of agroecology. Ocl 24, D307. doi:10.1051/ocl/2017028

689 Berthet, E.T., Hickey, G.M., 2018. Organizing collective innovation in support of sustainable agro-

690 ecosystems: The role of network management. Agric. Syst. 165, 44-54. 691 doi:10.1016/j.agsy.2018.05.016

692 Bournigal, J.-M., 2014. Définir ensemble le futur du secteur des agroéquipements. IRSTEA

693 Brédart, D., Stassart, P.M., 2017. When farmers learn through dialog with their practices : A proposal 694 for a theory of action for agricultural trajectories. J. Rural Stud. 53, 1-13. 695 doi:10.1016/j.jrurstud.2017.04.009

696 Brugnach, M., Dewulf, A., Pahl-Wostl, C., \& Taillieu, T. 2008. Toward a relational concept of 697 uncertainty: about knowing too little, knowing too differently, and accepting not to know. Ecology 698 and Society, 13(2), 30.

699 Cerf, M., Jeuffroy, M.H., Prost, L., Meynard, J.M., 2012. Participatory design of agricultural decision 700 support tools: Taking account of the use situations. Agron. Sustain. Dev. 32, 899-910. 701 doi:10.1007/s13593-012-0091-

702 Cerf, M., Meynard, J.-M., 2006. Les outils de pilotage des cultures : diversité de leurs usages et 703 enseignements pour leur conception. Natures Sci. Sociétés 14, 19-29. doi:10.1051/nss:2006004 
704 Chance, Q., Meyer, M., 2017. L'agriculture libre. Les outils agricoles à l'épreuve de l'open source. 705 Tech. Cult. 23.

706 Chesbrough, H.W., Vanhaverbeke, W., West, J., 2014. New Frontiers in Open Innovation. Oxford 707 University Press, Oxford.

708 Chizallet, M., Prost, L., Barcellini, F., 2019. Understanding the design activity of farmers in 709 agroecological transition: Towards a trilogical design model. Psychol. Fr. 64, 119-139. 710 doi:10.1016/j.psfr.2019.03.001

711 Coolsaet, B., 2016. Towards an Agroecology of Knowledges: Recognition, Cognitive Justice and 712 Farmers' autonomy in France, in: Global Governance/Politics, Climate Justice \& Agrarian/Social 713 Justice: Linkages and Challenges. 4-5 February 2016, The Hague, The Netherlands.

714 Darnhofer, I., Bellon, S., Dedieu, B., Milestad, R., 2010. Adaptiveness to enhance the sustainability of 715 farming systems. A review. Agron. Sustain. Dev. 30, 545-555. doi: 716 https://doi.org/10.1051/agro/2009053

717 Dedieu, B., Chia, E., Leclerc, B., Moulin, C.H., Tichit, M., 2008. L'élevage en mouvement. 718 Fléxibilité et adaptation des exploitations d'herbivores. Quae, Paris.

719 Dumez, H., 2013. Qu'est-ce que la recherche qualitative ? Problèmes épistémologiques, 720 méthodologiques et de théorisation. Ann. des Mines - Gérer Compr. 112, 29. 721 doi:10.3917/geco.112.0029

722 FAO, 2013. Mechanization for Rural Development: A review of patterns and progress, Integrated 723 Crop Management Vol. 20-2013. doi:10.1103/PhysRevLett.43.1494

724 Fourati-Jamoussi, F., 2018. Evolutions agrotechnique contemporaine II. Transformations de l'agro725 machinisme: fonction, puissance, information, invention, in: Caroux, C., Dubois, M., Sauvée, L. 726 (Eds.), Quelques Tendances de l'innovation Des Firmes de l'agro-Machinisme. Université de 727 technologies de Belfort-Montbéliard, Belfort-Montbéliard, pp. 71-81.

728 Gero, J., Kannengiesser, U., 2008. An ontology of Donald Schon's reflection in designing. Int. J. Des. 729 Sci. Technol. 15, 77-90.

730 Girard, N., Magda, D., Astruc, J.M., Couix, N., Gross, H., P Guyon, J., Labatut, J., Poinsot, Y., 731 Saldaqui, F., 2014. Analyzing indicators for combining natural resources management and 732 production-oriented activities. Environ. Dev. Sustain. 17, 155-172. doi:10.1007/s10668-014-9544-7

733 Guillou, M., Guyomard, H., Huyghe, C., Peyraud, J.-L., 2013. Vers des agricultures doublement 734 performantes pour concilier compétitivité et respect de l'environnement.

735 Hatchuel, A., Le Masson, P., Reich, Y., Eswaran, S., 2017. Design theory: a foundation of a new 736 paradigm for design science and engineering. Res. Eng. Des. doi:10.1007/s00163-017-0275-2 
737 Hatchuel, A., Weil, B., 2002. C-K theory: Notions and applications of a unified design theory. Proc.

738 Herbert Simon Int. Conf. « Des. Sci. »1-22.

739 Hatchuel, A., Weil, B., 2003. A new approach of innovative design: an introduction to C-K theory, in:

740 Folkeson, A., Gralen, K., Norell, M., Sellgren, U. (Eds.), International Conference on Engineering 741 Design. Stockholm, pp. 109-110.

742 Hatchuel, A., Weil, B., 2009. C-K design theory : an advanced formulation. Res. Eng. Des. 19, 181743 192. doi:10.1007/s00163-008-0043-4

744 Huh, J.-H., Kim, K.-Y., 2018. Time-Based Trend of Carbon Emissions in the Composting Process of 745 Swine Manure in the Context of Agriculture 4.0. Processes 6, 168. doi:10.3390/pr6090168

746 Jolly, C., Le Velly, R., Goulet, F., 2016. Agencer un nouveau marché pour les petits producteurs. Les 747 machines appropriées à l'agriculture familiale en Argentine, in: 10 Journées de Recherches En 748 Sciences Sociales, 8-9 December 2016, Paris, France.

749 Joly, P.-B., 2017. Beyond the Competitiveness Framework? Models of Innovation Revisited. J. Innov. $750 \quad$ Econ. 22, 79. doi:10.3917/jie.pr1.0005

751 Kilelu, C.W., Klerkx, L., Leeuwis, C., 2013. Unravelling the role of innovation platforms in 752 supporting co-evolution of innovation: Contributions and tensions in a smallholder dairy development 753 programme. Agric. Syst. 118, 65-77. doi:10.1016/j.agsy.2013.03.003

754 Kirui, O., von Braun, J., 2018. Mechanization in African Agriculture: A Continental Overview on 755 Patterns and Dynamics. SSRN Electron. J. doi:10.2139/ssrn.3194466

756 Klerkx, L., van Bommel, S., Bos, B., Holster, H., Zwartkruis, J. V., Aarts, N., 2012. Design process 757 outputs as boundary objects in agricultural innovation projects: Functions and limitations. Agric. Syst. 758 113, 39-49. doi:10.1016/j.agsy.2012.07.006

759 Le Masson, P., Weil, B., Hatchuel, A., 2017. Design Theory. Methods and Organization for 760 innovation. Springer Nature. doi: 10.1007/978-3-319-50277-9

761 Lindblom, J., Lundström, C., Ljung, M., Jonsson, A., 2016. Promoting sustainable intensification in 762 precision agriculture : review of decision support systems development and strategies. Precis. Agric. 763 18, 309-331. doi:10.1007/s11119-016-9491-4

764 Lucas, V., Gasselin, P., 2016. Farm machinery cooperatives: a new arena for agroecological 765 innovation?, in: WS8 - Innovations (Technological, Social, Market) and Farming Work. p. 11.

766 Lucas, V., De Tourdonnet, S., Barbier, J.-M., Cittadini, R., Gasselin, P., 2018. Le glyphosate en 767 agriculture de conservation: Un cas illustratif de la dépendance de l'agriculture française aux 768 pesticides, in: Journées de Recherches En Sciences Sociales. pp. 13-14. 
Mazoyer, M., Roudart, L., 2006. A history of world agriculture: from the neolithic age to the current crisis. Monthly Review Press.

Meynard, J., Dedieu, B., Bos, A., 2012. Re-design and co-design of farming systems. An overview of methods and practices, in: Darnhofer, I., Gibon, D., Dedieu, B. (Eds.), Farming Systems Research into the 21st Century: The New Dynamic. Springer, Paris, pp. 407-432. Meynard, J.-M., Jeuffroy, M.-H., Le Bail, M., Lefèvre, A., Magrini, M.-B., Michon, C., 2017. Designing coupled innovations for the sustainability transition of agrifood systems. Agric. Syst. doi:10.1016/j.agsy.2016.08.002

777

Nicholls, C.I., Altieri, M.A., 2018. Pathways for the amplification of agroecology. Agroecol. Sustain. Food Syst. 42, 1170-1193. doi:10.1080/21683565.2018.1499578

Onwude, D.I., Abdulstter, R., Gomes, C., Hashim, N., 2016. Mechanisation of large-scale agricultural fields in developing countries - a review. J. Sci. Food Agric. 96, 3969-3976. doi:10.1002/jsfa.7699 Papalambros, P.Y., 2015. Design Science: Why, What and How. Des. Sci. 1, e1. doi:10.1017/dsj.2015.1 Piovan, R., 2018. Les grandes questions sur l'évolution actuelle de l'agro-machinisme, in: Caroux, D., Dubois, M., Sauvée, L. (Eds.), Evolution Agrotechnique Contemporaine II. Transformations de 1'agro-Machinisme: Fonction, Puissance, Information, Invention. Université de technologie de Belfort-Montbélliard, pp. 29-32.

Pisante, M., Stagnari, F., Grant, C.A., 2012. Agricultural innovations for sustainable crop production intensification. Ital. J. Agron. 7, 300-311. doi:10.4081/ija.2012.e40

Prost, L., Berthet, E.T.A., Cerf, M., Jeuffroy, M.-H., Labatut, J., Meynard, J.-M., 2016. Innovative design for agriculture in the move towards sustainability: scientific challenges. Res. Eng. Des. doi:10.1007/s00163-016-0233-4

792 Ramin Shamshiri, R., K. Balasundram, S., J. Yule, I., Weltzien, C., Pitonakova, L., Chowdhary, G., E.

793 Grift, T., A. Hameed, I., 2018. Simulation software and virtual environments for acceleration of 794 agricultural robotics: Features highlights and performance comparison. Int. J. Agric. Biol. Eng. 11, 795 12-20. doi:10.25165/j.ijabe.20181104.4032

796

Rapidel, B., Traoré, B.S., Sissoko, F., Lançon, J., Wery, J., 2009. Experiment-based prototyping to design and assess cotton management systems in West Africa. Agron. Sustain. Dev. 29, 545-556. doi:10.1051/agro/2009016

Relf-Eckstein, J.E., Ballantyne, A.T., Phillips, P.W.B., 2019. Farming Reimagined: A case study of 800 autonomous farm equipment and creating an innovation opportunity space for broadacre smart farming. NJAS - Wageningen J. Life Sci. 90-91, 100307. doi:10.1016/j.njas.2019.100307 
802 Ronner, E., Descheemaeker, K., Almekinders, C., Ebanyat, P., Giller, K.E., 2019. Co-design of 803 improved climbing bean production practices for smallholder farmers in the highlands of Uganda.

804 Agric. Syst. 175, 1-12. doi:10.1016/j.agsy.2019.05.003

805 Salembier, C., Segrestin, B., Berthet, E., Weil, B., Meynard, J.M., 2018. Genealogy of design 806 reasoning in agronomy: Lessons for supporting the design of agricultural systems. Agric. Syst. 164, 807 277-290. doi:10.1016/j.agsy.2018.05.005

808 Schön, D. 1983. The reflective practitioner: how professionals think in action. Basic Books, New 809 York

810 Sigaut, F., 1989. La naissance du machinisme agricole moderne. Anthropol. Sociétés 13, 79-102.

811 Siggelkow, N., 2007. Persuasion with case studies. Acad. Manag. J. 50, 20-24. 812 doi:10.5465/AMJ.2007.24160882

813 Simon, H., 1969. The sciences of the artificial. MIT Press, London. doi:10.1016/S0898814 1221(97)82941-0

815 Sims, B., Kienzle, J., 2015. Mechanization of Conservation Agriculture for Smallholders: Issues and 816 Options for Sustainable Intensification. Environments 2, 139-166. doi:10.3390/environments2020139

817 Toffolini, Q., Jeuffroy, M.H., Prost, L., 2016. Indicators used by farmers to design agricultural 818 systems: a survey. Agron. Sustain. Dev. 36, 1-14. doi:10.1007/s13593-015-0340-z

819 Van der Ploeg, J.D. 2008. The new peasantries: struggles for autonomy and sustainability in an era of 820 empire and globalization. Earthscan.

821 Voß, J., Newig, J., Kastens, B., Monstadt, J., Nölting, B., 2007. Steering for Sustainable Development 822 - A typology of empirical contexts and theories based on ambivalence, uncertainty and distributed 823 power. J. Environ. Policy Plan. 9, 193-212. doi:10.1080/15239080701622881

824 Wolfert, S., Ge, L., Verdouw, C., Bogaardt, M.J., 2017. Big Data in Smart Farming - A review. 825 Agric. Syst. 153, 69-80. doi:10.1016/j.agsy.2017.01.023

826 Wynn, D.C., Clarkson, P.J., 2018. Process models in design and development. Res. Eng. Des. 29, 827 161-202. doi:10.1007/s00163-017-0262-7

828 Yin, R.K. (2003). Case Study Research: Design and Methods. Sage. Thousand Oaks, California.

829 Yoshikawa, H., 1981. General Design Theory and a CAD System, in: Sata, T., Warman, E. (Eds.), 830 Man-Machine Communication in CAD/ CAM. Proceedings of the IFIP WG5.2-5.3 working 831 conference 1980 (Tokyo), Amsterdam, pp. 35-57. 